\title{
Food Composition Data: Edible Plants in the Pampa
}

\author{
Adriana Carla Dias Trevisan, Vanuska Lima da Silva, \\ Josué Schneider Martins, Gabriela Coelho-de-Souza, Stefany Areva Severo, \\ and Mariana Oliveira Ramos
}

\begin{abstract}
Contents

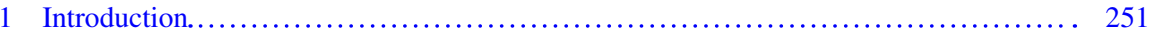

2 The Pampa and the Selection of its Edible Species.............................. 253

3 Edible and Medical Species of the Pampa: Ecology and Nutrition.................... 256

4 Final Considerations...................................................... 265

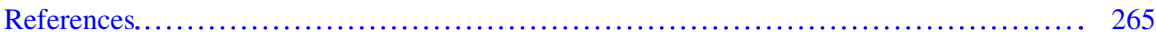

\section{Introduction}

Biomes with non-forest vegetation systems have been particularly neglected by public policies for conservation and sustainable development. This is precisely the case of the Pampa biome. Also known as southern Brazilian grasslands, the Pampa is a mosaic of different types of vegetation with a landscape that comprises savannah, steppe, steppic savannah, coast, transition areas, and semi-deciduous and deciduous forests (Chomenko and Bencke 2016) with a particular flora and fauna and great biodiversity (Quadros et al. 2008). In Brazil, it is only found in Rio Grande do Sul (RS) state, where it occupies nearly $63 \%$ of the territory (Suertegaray and Silva 2009). It has a unique cultural, genetic, and natural heritage with regional, national, and global importance. Despite this, from an official conservation perspective, only $0.4 \%$ of the Pampa is legally protected in conservation units, which is far from the global average of $17 \%$ per biome (Sosinski et al. 2019). Figure 1 presents an idea of the landscape of this biome, in which fields and forest islands coexist.

The conservation and sustained management of agrobiodiversity, through actions to support consumption of edible native species, are essential strategies for food and

\footnotetext{
A. C. D. Trevisan $(\bowtie) \cdot$ S. A. Severo

Universidade do Estado do Rio Grande do Sul/Ecos do Pampa, Santana do Livramento,

RS, Brazil

e-mail: adriana-trevisan@uergs.edu.br

V. L. da Silva · J. S. Martins · G. Coelho-de-Souza · M. O. Ramos

Universidade Federal do Rio Grande do Sul, Porto Alegre, RS, Brazil
}

(C) The Author(s), under exclusive license to Springer 


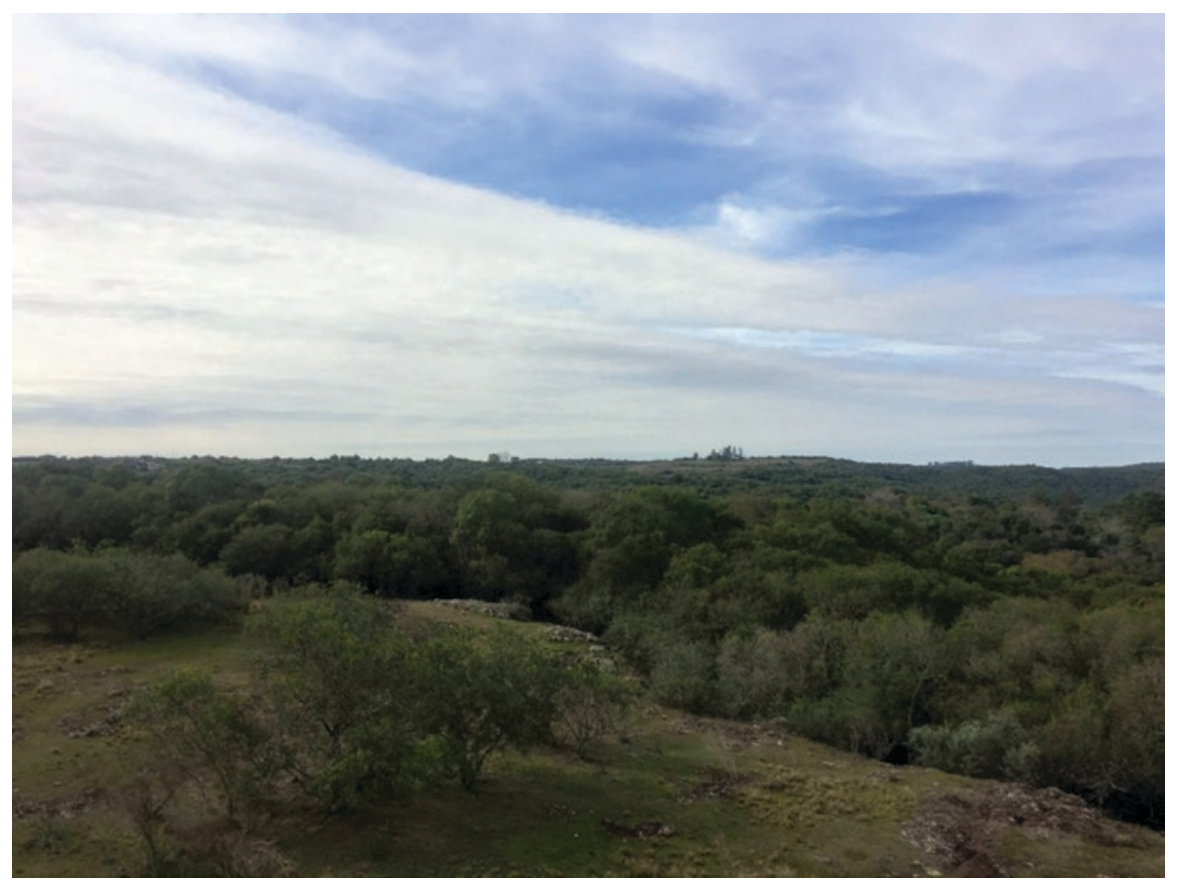

Fig. 1 Mosaic of ecosystems in the Pampa, Santana do Livramento, RS. (Photo: Trevisan ACD/ Echoes of the Pampa)

nutritional sovereignty and security. Knowledge about the species' nutritional composition has an essential role in advancing these strategies. Some of the species have higher nutrient concentrations of carotenoids, fibers, anthocyanins, vitamins, and minerals than foods commonly consumed (Martins et al. 2019; Rockett et al. 2020; Schmidt 2018b). From a nutritional and phytochemical perspective, the edible native species of the Pampa biome have strong potential to be included in the diet of the population.

In this chapter, we present nine native food plants from the Pampa with different common uses among local people: six are eaten, one used as a spice, and two taken as tea for medicinal purposes. In addition, the three species used as spices and medicine have an important role in the ecological landscape because they provide ecosystem services to food systems. Schinus molle L. offers an abundance of food to avifauna that are predators of many undesirable insects. The intense fluorescence of Aloysia gratissima (Gillies \& Hook) Tronc helps to maintain pollinators, while Elionurus muticus (Spreng.) Kuntze is a companion plant to Butia yatay (Mart.) Becc. and marks the territory of family farms because this medicinal plant is found in the butiazal understory where there is animal grazing (Curicaca et al. 2018; Lemos et al. 2014). This chapter is composed of three sections, in addition to the introduction. The first explains how the species were chosen, considering their ecology and nutritional composition. The final considerations reflect on gaps in existing knowledge. 


\section{The Pampa and the Selection of its Edible Species}

The long history of environmental degradation and contamination caused by industrial husbandry, associated with landownership concentrated in large properties, has devalued the use of species from the Pampa. Cultural practices forged by pressure from the dominant economic model have led to neglect of the Pampa's natural heritage, which has been forgotten by inhabitants of the territory. Local species with great food and economic potential are not only neglected but are often also suppressed, given that they are thought to "pollute the fields." Nevertheless, studies are underway in the territory that demonstrate opportunities for sustainable use of the Pampa's natural heritage, serving to generate income and stimulate social development and reproduction of local communities.

From the perspective of sustainable use of edible species from biodiversity, it is necessary to understand the ecology of each species, to be able to guide practices linked to handling of natural populations and/or domestication of the species. To manage the natural population, it is understood that the strategies used should be specific to each species, correlating with their ecological plasticity. When planning domestication, it is important to emphasize that given the large genetic variation within populations, it is always necessary to define the objectives of selection, that is, to determine if the intention is production of fruits, juices, spices, teas, essential oils, fibers, crafts, or phytotherapeutic products. Studies demonstrate that various native vegetable species of Brazilian flora have significant quantities and varieties of nutrients such as food fibers, minerals, and vitamins (Rockett et al. 2020; Schmidt 2018b; Seraglio et al. 2018; SiBBr 2020), and they have revealed antioxidant (Dalla Nora et al. 2014a; Rockett et al. 2020), antihyperglycemic (Vinholes et al. 2017), and anti-inflammatory properties. It is also important to highlight that scientific studies have related the consumption of anthocyanins and carotenoids to protection of the human organism and to reducing risk of developing non-transmissible chronic diseases (Sampaio and Almeida 2009; Strack and Souza 2012) including Alzheimer's (Silveira et al. 2011). Each one of the fruits has structural peculiarities, such as strong or fragile seeds, smooth or fibrous bark, fluid, or dense pulp, so that their processing becomes an important challenge that must be studied and understood.

Thus, in addition to the need to revive local knowledge, the creation of environments of innovation that offer support by linking the knowledge between local peoples and research institutions is of strategic importance today. One of the environments of innovation being developed in the Pampa is found at the Universidade Estadual do Rio Grande do Sul (UERGS), in the research and extension group "Ecology of Knowledge in agroecosystems of the Pampa biome - Echoes of the Pampa" that has been collecting results with the species presented in this chapter. In addition to "Echoes of the Pampa," the choice and description of the species was assisted by research groups at the Universidade Federal do Rio Grande do Sul (UFRGS) that work with food and nutritional sovereignty while emphasizing the ecology of knowledge and sustainable use of biodiversity anchored in species important to local communities. The species presented here (Table 1) were selected 
Table 1 Selected food and medicinal species of the Pampa biome

\begin{tabular}{|c|c|c|c|c|}
\hline & Scientific name & Popular names & Family & Habit \\
\hline 1 & $\begin{array}{l}\text { Butia odorata (Barb. } \\
\text { Rodr.) Noblick) }\end{array}$ & Butiá, coquinho-azedo, butiazeiro & Arecaceae & Arboreal \\
\hline 2 & Butia yatay (Mart.) Becc. & Butiá-jataí, jataí, yatai,yatay & Arecaceae & Arboreal \\
\hline 3 & Eugenia involucrata D.C. & $\begin{array}{l}\text { Cerejeira-do-rio-grande, cerejeira- } \\
\text { do-mato, cereja do-rio-grande, } \\
\text { cereja-do-mato }\end{array}$ & Myrtaceae & Arboreal \\
\hline 4 & $\begin{array}{l}\text { Myrcianthes pungens } \\
\text { (O.Berg.) D. Legrand }\end{array}$ & Guabijú, guabijuzeiro & Myrtaceae & Arboreal \\
\hline 5 & $\begin{array}{l}\text { Guettarda uruguensis } \\
\text { Cham. \& Schltd }\end{array}$ & Veludinha, veludinho & Rubiaceae & Arboreal \\
\hline 6 & $\begin{array}{l}\text { Acanthosyris spinescens } \\
\text { (Mart. \& Eichler) Griseb }\end{array}$ & Sombra de touro, quebracho-rojo & Santalaceae & Arboreal \\
\hline 7 & Schinus molle L. & Anacauita, piriquiteira, aroeira-sala & Anacardiaceae & Arboreal \\
\hline 8 & $\begin{array}{l}\text { Aloysia gratíssima } \\
\text { (Gillies \& Hook) Tronc. }\end{array}$ & $\begin{array}{l}\text { Garupá, alfazema-do-Brasil, mimo } \\
\text { do Brasil, cedrón-del-monte }\end{array}$ & Verbenaceae & Shrub \\
\hline 9 & $\begin{array}{l}\text { Elionurus muticus } \\
\text { (Spreng.) Kuntze }\end{array}$ & Capim-corona, Capim-limão & Poaceae & Herbaceous \\
\hline
\end{tabular}

with a focus on three principal criteria: (1) having popular use, (2) proven multifunctionality, and (3) being linked to agroecological productive systems for management of pasture and or agroforestry systems.

The species presented in this chapter represent only a sample of the potential that the botanic biodiversity of the Pampa offers to local communities in terms of food and nutritional security as well as the potential to generate income. The information is based on the results of studies being conducted by UERGS/Echoes of the Pampa and at the Universidad de la Republica del Uruguay in the Pampa territory. Specifically, to select the priority species we present here, we prepared an analysis matrix with data from floristic surveys in home gardens, interviews with farmers, and discourse analysis of participants in a radio program that each week discusses a plant species from the Pampa. The data matrix allowed identifying the most common species in home gardens and those best known to Pampa residents. This led to the selection of thirty-five species from which the authors of this chapter selected nine species based on the criteria presented in the previous paragraph.

Due to the scarcity of scientific publications, only three species (B. odorata, $M$. pungens, and E. involucrata) will have their nutritional and phytochemical composition presented. For the other species, articles were found that examine their biological properties, such as fungicidal, bactericidal, and insecticidal or as food preservatives, but not their use as food. It is essential to establish links between local production systems and the diffusion of knowledge about biodiversity to expand reflections about cultural habits and preferences and to intensify the sustainable use and conservation of the biome. The dominant productive model in the territory, which gives little value to local knowledge, combined with regional asymmetries of development and gaps in scientific studies about the Pampa, is an impediment to 
increasing value and stimulating innovation with sociobiodiversity. Figure 2 presents images of some of the species presented, to introduce readers not only to the colors, textures, and shapes described but to the diversity found in the Pampa.

Sociobiodiversity is understood to be the relation between biological diversity, traditional agricultural systems, and the use and management of these resources combined with the knowledge and culture of traditional communities and family farmers (BRASIL 2000, 2009). This concept comes from the Brazilian discussion around the sustainability of extractivism while recognizing the diversity and importance of traditional peoples and family farmers. Experiences in the construction of sociobiodiversity product chains have demonstrated the capacity for inclusion of family farmers, extractivists, traditional peoples, and communities that manage and conserve native biodiversity. This reality has contributed to the supply of healthy,
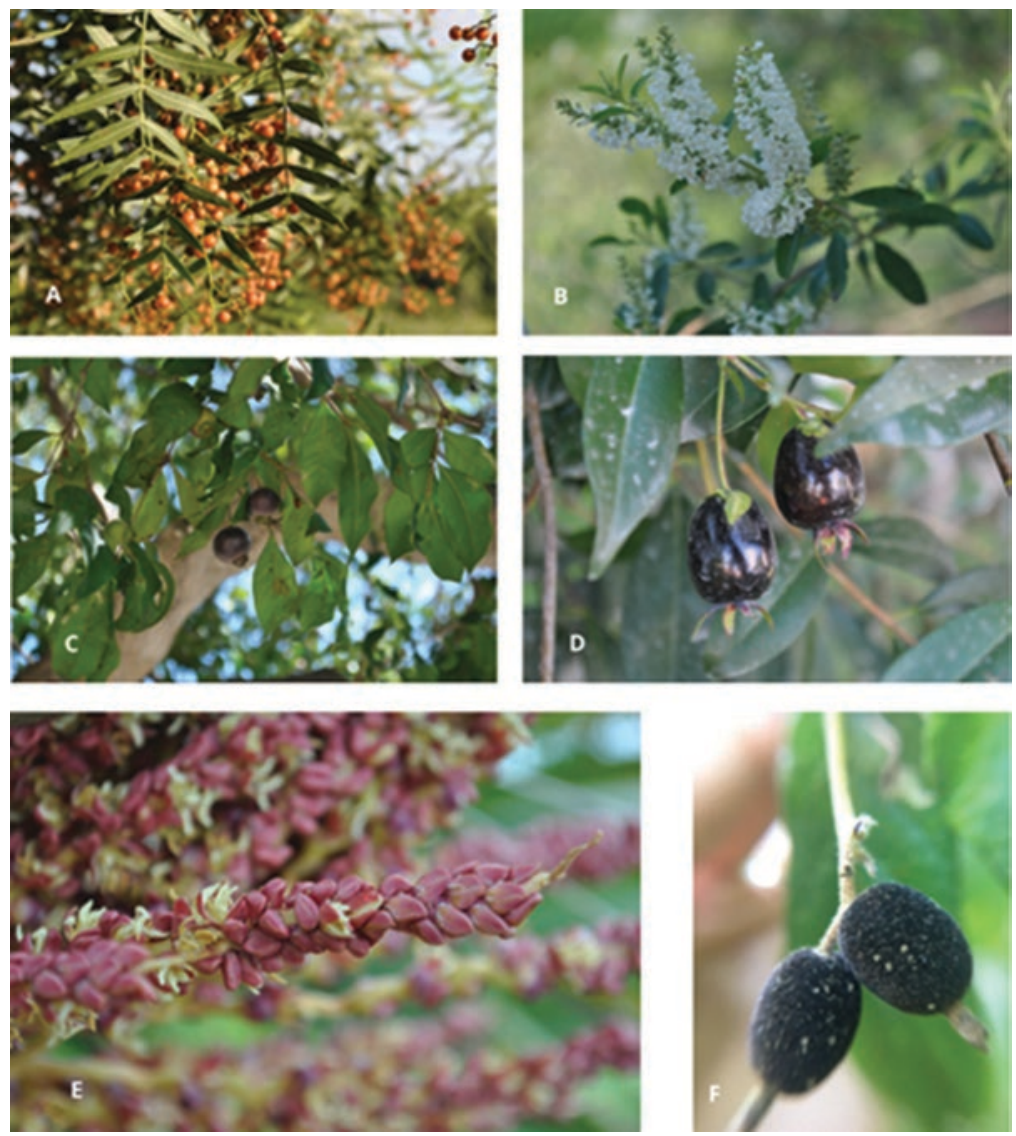

Fig. 2 Fruits and flowers of sociobiodiversity of the Pampa biome. (a) Anacauíta (S. molle), (b) garupá (A. gratissima), (c) guabijú (M. pungens), (d) cerejeira-do-rio-grande (E. involucrata), (e) butiá (B. odorata), (f) veludinha (G. uruguensis) (Photos from Echoes of the Pampa: Lika Furtado $(\mathbf{a}-\mathbf{e})$ and Franciely Pando (f)) 
fresh food or with little processing, with high nutritional values, which is increasingly necessary considering the poor diets, malnutrition, and overweight condition of most of the Brazilian population (Ramos et al. 2017; Tutwiler et al. 2017). In the case of the Pampa biome, it is necessary to overcome the negligence and underutilization of many native species that have multiple potentials for food, medicinal, aromatic, and cosmetic uses. As we present in this chapter, we believe that overcoming the existing gaps in knowledge and giving value to the use of these species should take place by supporting the ecology of knowledge, guaranteeing the qualified participation of local communities. The governance processes used in this production of knowledge are essential to protect traditional knowledge, guarantee the sharing of benefits, and avoid that knowledge is appropriated by distant actors with greater economic and political power. Moreover, to overcome the current situation, it is necessary to redesign the productive units in the Pampa to promote resilience based on biodiverse productive systems from an agroecological perspective.

\section{Edible and Medical Species of the Pampa: Ecology and Nutrition}

The species selected are potential resources for the development of sustainable productive systems in the Pampa. The ecological aspects presented are the result of a review of the literature and primary data from extension and research projects being executed by the Echoes of the Pampa at UERGS. The databases researched were Portal de Periódicos Capes, SciELO, ScienceDirect, and Redalyc (from 1959 to present). The search descriptors were the scientific names of the nine species presented here, and the inclusion criteria were articles and theses that address species use, sociobiodiversity, or species ecology. With the same search descriptors, the data about nutritional composition are also presented from a review conducted by researchers at UFRGS in the following databases: Web of Science, Bireme, SciELO, Scopus, ScienceDirect, and CAPES (without limiting the time period), in addition to research in The Brazilian Biodiversity Information System ( $\mathrm{SiBBr}$ ) of the Ministry of Science, Technology, Innovation and Communications (MCTIC), with technical support from the United Nations Environment Program (UNEP) and financial support from the Global Environmental Fund (GEF). The inclusion criteria were articles and theses with results that address phytochemical and nutritional qualities.

\section{The Butiás}

The butiá or Brazilian palms are composed of the Butia genus in the Arecaceae family and are found from Bahia and Goiás to Rio Grande do Sul and neighboring countries (Rodrigues et al. 2008). All the butiás originate from mother plants whose stem grows below ground level and form a natural gregarious population with large production of edible fruits (Meerow et al. 2009). The butiazais, as butiá palm groves are known, have a strategic role in the conservation and restoration of the Pampa 
biodiversity, because by forming islands in the landscape of open fields, they increase ecological resilience by promoting connectivity. The Brazilian palm groves are extremely threatened by the absence of regeneration due to their elimination by intensive cattle grazing and agriculture and expansion of urban areas (Fonseca 2014). Given this situation, the Rota dos Butiazais, a project that attracts tourists to family farms, is an example of a strategy for environmental conservation and sustainable use of biodiversity associated with the butiazais that has been developed since 2016, promoting integration between Brazil, Uruguay, and Argentina (Embrapa 2017; Sosinski et al. 2019).

In the Pampa biome, six species stand out, and the most characteristic are $B$. odorata, B. yatay, and B. lallemantii. B. yatay and B. lallemantii are endemic to the Pampa (Leitman et al. 2015; Soares et al. 2014). The large intra-populational genetic variation as well as the small number of individuals within these natural populations is a challenge to the conservation and use of the butiazais. Beyond the direct use of the fruits as food, there is also unexplored potential of the compounds in the pulp and seeds of the butiá fruit. Due to the large number of publications about them and because they are more commonly explored commercially, and are even among the species processed and sold by the Cadeia Solidária das Frutas Nativas no RS (Ramos 2019), we are able to present data for B. odorata and B. yatay.

(a) Butiá

\section{Butia odorata}

The species B. odorata was initially described in 1826 as Cocos capitata and until 2010 was denominated as B. capitata (Noblick 2011). It is known locally as bitter small coconut, butiazeiro, or butiá and occurs in ecosystems of the Atlantic Forest and Pampa biomes. It produces fruit once a year, flowers from October to December, and bears fruit from January to April (Büttow et al. 2009). Ecologically it occurs in savannah formations, as palm or butiá groves in poor soil with low water retention capacity. Its fruits are dispersed between the summer and early fall in arrangements of dormant seeds that require the conditions found in the islands of butiazais to be able to germinate and thus naturally regenerate (Schlindwein 2012). Thus, like the inflorescences, the fruits of lemon yellow to fire red coloring vary considerably in size (Mistura et al. 2012). The seed bunch can be considered ripe and ready for picking when at least half of the fruits have uniform color.

Among the edible uses of the butiá we can cite manufacturing of oil from the seed endosperm, collection of the sap that flows from the apical meristem after cutting the plant, extraction of hearts of palm, and raw consumption and processing of the fruits in the form of jellies, liquors, ice cream, and sweets (Büttow et al. 2009; Rivas and Barbieri 2017). Moreover, numerous crafts are made from them, and they are elegantly used in landscaping (Büttow et al. 2009; Geymonat and Rocha 2009; Sganzerla 2010). Important projects in the agroecological movement have given value to the fruits of the species and their associated ecosystems by production of butiá juice and frozen pulp (Ramos 2019). The yield of the pulp production varies between 50 and $60 \%$ of total fruit weight, without addition of water, and the pulp 
can be maintained frozen for up to 1 year, without significant sensory or nutritional changes.

Both the pulp and kernels have important nutritional properties. Although they are normally discarded after pulping, the butiá seeds have a kernel of high nutritional value. The $B$. odorata seed was found to have a high protein content (from 12 to $15 \mathrm{~g} / 100 \mathrm{~g})$, fat (10 g/100 g), as well as minerals such as phosphorus, magnesium, and potassium (Faria et al. 2008). Its pulp is generally acidic (pH lower than 4,5) and has high fiber ( 1 to $4 \mathrm{~g} / 100 \mathrm{~g}$ ) and vitamin (vitamins A and C) content as well as various minerals (including iron, zinc, and magnesium) (Table 2).

Another important factor is the presence of bioactive compounds and chemical elements with antioxidant properties, among which it is worth noting carotenoids and phenolic compounds. The maximum and minimum values available in the literature for total carotenoids in B. odorata are proportional to other recognized nutritional species such as cajá (3,86 mg/100 g), araticum (1249 mg/100 g), and another butiá species, Butia eriospatha $(1,73 \mathrm{mg} / 100 \mathrm{~g})$.

(b) Butiá-jataí

\section{Butia yatay}

B. yatay has many botanical similarities with $B$. witeckii, B. quaraimana, and $B$. paraguayensis, which generates controversies among researchers, including hypotheses that the natural populations are the result of plantings. B. yatay has its etymology linked to its small hard fruit and is known as butiá-jataí, jataí, or yatay in Spanish. It is widely distributed in Argentina and Uruguay but in Brazil occurs only in two specific regions of Rio Grande do Sul, one in a typical Pampa region and

Table 2 Nutritional composition of butiá (Butia odorata) per $100 \mathrm{~g}$ of fruit pulp with natural moisture content ${ }^{\mathrm{a}}$

\begin{tabular}{l|l|l|l|l}
\hline Nutrient & Min. & Max. & Med. & \%RDI \\
\hline Carbohydrates $(\mathrm{g} / 100 \mathrm{~g})^{\mathrm{b}}$ & 6,58 & 14,84 & 10,71 & 8,24 \\
\hline Proteins $(\mathrm{g} / 100 \mathrm{~g})^{\mathrm{d}}$ & 0,60 & 5,28 & 2,94 & 5,25 \\
\hline Fats $(\mathrm{g} / 100 \mathrm{~g})^{\mathrm{c}}$ & 0,11 & 2,41 & 1,26 & 2,29 \\
\hline Food fiber $(\mathrm{g} / 100 \mathrm{~g})^{\mathrm{b}}$ & 0,84 & 4,89 & 2,87 & 20,46 \\
\hline Carotenoids $(\mathrm{mg} / 100 \mathrm{~g})$ & 2,80 & 5,50 & 4,15 & - \\
\hline Anthocyanins $(\mathrm{C} 3 \mathrm{Gmeq} / 100 \mathrm{~g})$ & 1,05 & 25,13 & 13,09 & - \\
\hline${\text { Vitamin C }(\mathrm{mg})^{\mathrm{b}}}^{\text {Vitamin K }(\mathrm{mg})^{\mathrm{e}}}$ & 23,00 & 63,84 & 43,42 & 48,24 \\
\hline $\mathrm{Mg}(\mathrm{mg})^{\mathrm{b}}$ & 165 & 462 & 313,50 & 9,22 \\
\hline Capion: & 4,0 & 12,0 & 8,00 & 1,90 \\
\hline
\end{tabular}

Caption: Min, minimum amounts; max, maximum amounts; med, medium of the minimum and maximum amounts found in literature; \% RDI, percent of recommended daily intake

${ }^{a}$ Conversion was realized, when necessary, from a dry base (dehydrated food) to food with its natural moisture content

${ }^{b}$ Institute of Medicine (2006), to adult men

'RDC 269/2005 Brasil (2005); g, gram; $\mu$ g, micrograms; mg, milligrams

${ }^{\mathrm{d} C}$ Calculated to a man of $70 \mathrm{~kg}$

'Institute of Medicine (2019)

Sources: Hoffman et al. (2014), Ferrão et al. (2013), and Fonseca (2012) 
another in Giruá, a municipality in the Atlantic Forest (Marchiori et al. 1995; Patterer et al. 2019).

In the Pampa, it is found in the well-known Palmar de Coatepe palm grove, in the municipality of Quaraí, which occupies $60 \mathrm{~km}^{2}$ and is a disjunction from its center of distribution in Argentina, the "Palmar Grande" (Marchiori et al. 1995; Marchiori and Alves 2011). This natural population with 4-8-m-tall solitary stems that are $20-30 \mathrm{~cm}$ in diameter has low densities of individuals due to cattle grazing, which compromises natural regeneration and population viability (Marchiori et al. 1995; Marchiori and Alves 2011). The flowers may be yellow, green, or purplish and the fruits yellow and purplish when ripe (Soares et al. 2014).

Considering its phytochemical composition, four classes of phenolic compounds stand out, coumarins, flavonoids, saponins, and tannins (Matos and Muller 2019), with potential for multiple uses. From a nutritional perspective, Martins and collaborators (2019) identified a significant presence of food fiber $(9,0 \mathrm{~g} / 100 \mathrm{~g}$ in the fruit and 4,7 g/100 $\mathrm{g}$ in the pulp) and vitamin $\mathrm{C}(72,8 \mathrm{mg} / 100 \mathrm{~g}$ in the pulp in 100 grams of butiá-yatai. These amounts allow categorizing this food as rich in food fibers and vitamin $\mathrm{C}$, to the degree that consumption of $100 \mathrm{~g}$ of the fruit represents more than $15 \%$ and $100 \%$, respectively, of RDI of these nutrients by the Ministry of Health (Martins et al. 2019).

\section{Cerejeira-do-rio-grande}

\section{Eugenia involucrata}

The Myrtaceae family is a broad family with 27 genera and 1026 species in Brazil, with 73\% of these endemic (Sobral et al. 2015; Vasconcelos et al. 2017). In the Pampa biome, 8 genera and 17 species are described (Flora do Brasil 2020a) and, as in the other biomes where it is found, have important value in the floristic component of the arboreal stratum with a large vector of diversity because of their endemism. One characteristic of the seeds of this family is a low tolerance to drying; thus, the production of seedlings must be conducted soon after pulp removal or collection. The Myrtacea have aromatic flowers and many glands, normally trichomes, which store essential oils (Oliveira 2018). Among the genera in the family, Eugenia stands out as the most representative in Brazil, with 392 species, 303 of which are endemic (Flora do Brasil 2020b), with strong food potential due to their fruits with a marked flavor.

One of the important species of this genus is Eugenia involucrata, whose center of diversity is the Atlantic Forest with dispersal to the Pampa. It is known as cerejeira-do-mato, cerejeira-do-rio-grande, cerejeira-da-terra, pitanga-preta, cerezadel-monte (espanhol), and îwîrá-yepiró (guarani) and occurs at a range of altitudes and latitudes (Carvalho 2008; Martinez-Crovetto 1968; Praderi 1959). The average trees are from 10 to 15 meters tall, and it is considered a rare species, with low densities per area (Pase do Prado 2009). It is commonly found in backyards on farms in the Pampa. Its fruit production is intense and for this reason is highly sought by animals, which are its natural dispersers, and generates an important bank of plantules for regeneration. In addition to consumption of the raw fruit, the tea from an infusion of the leaves has popular local use for gastric problems, diarrhea, ulcers, 
and inflammations. It has proven antioxidant, anti-inflammatory, and antinociceptive effects (Barzotto 2019; Marin et al. 2008; Nicácio et al. 2017).

E. involucrata is among the Myrtacea species found in the Pampa with strong potential for production. Data from research and extension projects point to fruit production; however, there is a strong trend toward a multiple use of the species that includes the production of essential oils, natural extracts, and isolation of active phytochemical compounds. It is a soft, sweet, and slightly acidic fruit with yellowish-red to dark red color and is found in various sizes. It has up to four stiff and large seeds, with relatively sensitive integument. For this reason, the processing of this fruit is a bit more complex than that of butiá and guabiju, because breaking the seeds releases compounds into the pulp that are sensorially undesirable. However, after extraction of the pulp, various products can be prepared such as juices, sweets, and cakes.

Table 3 presents the nutritional data for the cerejeira-do-rio-grande. As is common in fruits, the cereja has a low energy density due to its high moisture (of about 90\%) and low fat and protein content. In general, the data indicate the presence of significant quantities of iron, copper, and magnesium. The carotenoid content in the pulp of the cereja-do-rio-grande is significant and is comparable to other fruits rich

Table 3 Nutritional composition of the pulp of the cerejeira-do-rio-grande (E. involucrata) with natural moisture content ${ }^{\mathrm{a}}$

\begin{tabular}{|c|c|c|c|c|}
\hline Nutrient & Min. & Max. & Med. & $\%$ RDI \\
\hline Carbohydrates $(\mathrm{g} / 100 \mathrm{~g})^{\mathrm{b}}$ & 3,46 & 8,27 & 5,87 & 4,51 \\
\hline Proteins $(\mathrm{g} / 100 \mathrm{~g})^{\mathrm{d}}$ & 0,62 & 0,94 & 0,78 & 1,39 \\
\hline Fats $(\mathrm{g} / 100 \mathrm{~g})^{\mathrm{c}}$ & 0,21 & 0,37 & 0,29 & 0,53 \\
\hline Food fiber $(\mathrm{g} / 100 \mathrm{~g})^{\mathrm{b}}$ & 1,30 & 1,70 & 1,50 & 10,71 \\
\hline $\mathrm{Fe}(\mathrm{mg} / 100 \mathrm{~g})^{\mathrm{b}}$ & 0,41 & 2,43 & 1,42 & 17,75 \\
\hline $\mathrm{Zn}(\mathrm{mg} / 100 \mathrm{~g})^{\mathrm{b}}$ & 0,09 & 0,14 & 0,12 & 1,05 \\
\hline $\mathrm{K}(\mathrm{mg} / 100 \mathrm{~g})_{\mathrm{e}}$ & 154,80 & 204,68 & 179,74 & 5,29 \\
\hline $\mathrm{Na}(\mathrm{mg} / 100 \mathrm{~g})^{\mathrm{e}}$ & 0,63 & 1,29 & 0,96 & 0,06 \\
\hline $\mathrm{Ca}(\mathrm{mg} / 100 \mathrm{~g})^{\mathrm{b}}$ & 11,20 & 13,74 & 12,47 & 1,25 \\
\hline$P(m g / 100 g)^{c}$ & 5,73 & 6,24 & 5,99 & 0,83 \\
\hline $\mathrm{Mg}(\mathrm{mg} / 100 \mathrm{~g})^{\mathrm{b}}$ & 6,96 & 12,26 & 9,61 & 2,29 \\
\hline $\mathrm{Mn}(\mathrm{mg} / 100 \mathrm{~g})^{\mathrm{b}}$ & 0,09 & 0,16 & 0,13 & 5,43 \\
\hline $\mathrm{Cu}(\mathrm{mg} / 100 \mathrm{~g})^{\mathrm{b}}$ & 0,06 & 0,09 & 0,08 & 8,33 \\
\hline Total carotenoids $(\mathrm{mg} / 100 \mathrm{~g})$ & 8,92 & 20,21 & 14,57 & - \\
\hline Vitamin A $(\mu \mathrm{g} . E A R / 100 \mathrm{~g})^{\mathrm{b}}$ & 26,00 & 899,38 & 462,69 & 51,41 \\
\hline
\end{tabular}

Caption: Min, minimum amounts; max, maximum amounts; med, medium; \% RDI, percent of recommended daily intake

${ }^{a}$ Conversion was realized, when necessary, from a dry base (dehydrated food) to food with its natural moisture content

'Institute of Medicine (2006), to adult men

'RDC 269/2005 Brasil (2005); g, gram; $\mu \mathrm{g}$, micrograms; mg, milligrams. EAR: Retinol equivalent ${ }^{\mathrm{d} C}$ Calculated to a man of $70 \mathrm{~kg}$

'Institute of Medicine (2019)

Source: Camlofski (2008), Schmidt (2018b), SiBBr (2020), and Schmidt (2018a) 
in this nutrient such as guabiroba $(24,58 \mathrm{mg} / 100)$, pequi $(15,28 \mathrm{mg} / 100 \mathrm{~g})$, and tucumã $(6,26 \mathrm{mg} / 100 \mathrm{~g})$ according to the data available from the Brazilian Biodiversity Information System ( $\mathrm{SiBBr} 2020)$.

The quantities of bioactive compounds such as phenols, vitamins, and pigments presented in this table may vary with processing factors such as light incidence, contact with oxygen, and exposure to heat, as well as agronomic factors such as production location, climate conditions, and the degree of ripeness of fruits. The levels of carotenoids and vitamin A present in the butiá pulp should be emphasized, given that they are very important elements in a healthy diet.

\section{Guabiju}

Myrcianthes pungens

Also, in the Myrtacea family, M. pungens, known as guabijú or guabijuzeiro, grow as trees up to $30 \mathrm{~m}$ tall and are found in the Atlantic Forest and Pampa (Lorenzi 2008; Sobral et al. 2015; Venzke 2012). There are registers of blossoming from September to January and fruit bearing from January to March (Fior et al. 2010; Guollo 2019). It is a species that ecologically occupies an advanced successional state and for this reason requires specific conditions of shade and soil quality to develop. The species is important to the promotion of local fauna because of its attractive and succulent fruits. Thus, among 181 species described as priority for recovery of typical Pampa ecosystems, $M$. pungens is indicated for forest and savannah formations (Guarino et al. 2018). Its wood is considered commercially important and can be used in civil construction and fine cabinet making and in the production of handles for tools and agricultural equipment. It is a heavy, elastic, strong, and dense wood (dos Santos and Marchiori 2014).

The guabiju stands out for its sweet flavor, and for this reason, together with E. involucrata, over time, it was selected for inclusion in domestic backyards in the Pampa. It is a small fruit with a quite fragile structure, with smooth skin that is easily separable from the pulp. Table 4 presents scientific data about the nutritional and phytochemical properties of $M$. pungens.

This data indicates strong nutritional potential, considering that guabiju has significant amounts of carotenoids and anthocyanins. These two compounds are responsible for the more orange-yellow internal and dark purple external color of the fruit. Fruit processing in general has significant impact on the degradation of bioactive compounds such as anthocyanins and total carotenoids in guabiju. Dalla Nora et al. (2014a) report that while the anthocyanin content in $100 \mathrm{~g}$ of fresh fruit is $231,2 \mathrm{mg}$, it is reduced to $13,53 \mathrm{mg}$ in $100 \mathrm{~g}$ of dry fruit due to the sensibility of this compound to exposure to heat.

\section{Veludinha}

\section{G. uruguensis}

The Rubiaceae family is the fourth largest family among the angiosperms. Among the Rubiaceae, the Guettarda stands out with 21 species identified in Brazil in various types of vegetation (Pereira and Kinoshita 2013). G. uruguensis is the only species that occurs in Rio Grande do Sul and is also found in Uruguay and Argentina (Barbosa et al. 2015; Piaggio and Delfino 2009; Takáts and Toselli 2015). 
Table 4 Nutritional composition of guabiju pulp (M. pungens) with natural moisture content ${ }^{\mathrm{a}}$

\begin{tabular}{l|l|l|l|l}
\hline Nutrient & Min. & Max. & Méd. & \%RDI \\
\hline${\text { Carbohydrates }(\mathrm{g} / 100 \mathrm{~g})^{\mathrm{b}}}^{\mathrm{a}}$ & 12,39 & 12,41 & 12,40 & 9,54 \\
\hline Proteins $(\mathrm{g} / 100 \mathrm{~g})^{\mathrm{d}}$ & 0,55 & 0,56 & 0,55 & 0,99 \\
\hline Fats $(\mathrm{g} / 100 \mathrm{~g})^{\mathrm{c}}$ & 0,05 & 0,06 & 0,06 & 0,10 \\
\hline Food fiber $(\mathrm{g} / 100 \mathrm{~g})^{\mathrm{b}}$ & 6,21 & 6,23 & 6,22 & 44,43 \\
\hline Carotenoids $(\mathrm{mg} / 100 \mathrm{~g})^{\text {Anthocyanins }(\mathrm{meq} \mathrm{C} 3 \mathrm{G} / 100 \mathrm{~g})}$ & 0,96 & 0,96 & 0,96 & - \\
\hline $\mathrm{Na}(\mathrm{mg} / 100 \mathrm{~g})^{\mathrm{e}}$ & 13,52 & 295,41 & 154,47 & - \\
\hline
\end{tabular}

Caption: Min, minimum amounts; max, maximum amounts; med, medium; \% RDI, percent of recommended daily intake

${ }^{a}$ Conversion was realized, when necessary, from a dry base (Dehydrated food) to food with its natural moisture content

${ }^{b}$ Institute of Medicine (2006), to adult men

'RDC 269/2005 Brasil (2005) g, gram; $\mu$ g, micrograms; mg, milligrams

${ }^{\mathrm{d} C}$ Calculated to a man of $70 \mathrm{~kg}$

'Institute of Medicine (2019)

Source: Andrade et al. (2011), Dalla Nora et al. (2014a, b), and Seraglio et al. (2018)

This species is known as veludinha, due to its furry leaves and branches, or palocruz, in Spanish, due to the stipules that look like thorns in the form of a cross (Newton 1986).

It is described as a small tree, 3 to $10 \mathrm{~m}$ tall, with opposite leaves, pedunculated flowers, and drupaceous fruits with 2-9 seeds (Duarte et al. 2014; Pereira 2007). It has a caducous characteristic, losing up to $90 \%$ of its leaves in winter, blossoming peaks in November-December and fruit bearing in January-February (Athayde et al. 2009). To highlight its edible potential, it begins to fruit 2-3 years after planting (Teixeira et al. 2019). Biological studies indicate that the veludinha has antimicrobial and antioxidant activities (Duarte et al. 2014). Moreover, its phytochemical compounds have potential use as allelopathic products (Duarte et al. 2017).

It is an ornamental species that has aromatic flowers and is highly sought by bees, being indicated for apiculture (Duarte et al. 2017). It has strong potential in landscaping and urban tree planting, due to its fast growth, ease of pruning, the aesthetic of its architecture, white flowers, and purplish fruits. Landscapers often use the veludinha in clumps in large areas with harmonious results.

\section{Sombra-de-touro}

\section{Acanthosyris spinescens}

The Santalaceae family has 39 genera with 13 of them found in Brazil ( $\mathrm{SiBBr}$ 2020). Among the genera occurring in Brazil stands out Acanthosyris, with only two Brazilian species and only one that occurs naturally in the Pampa biome: A. spinescens (Dettke and Caires 2015). It is known as sombra-de-touro, quebracho-rojo, or quebrachillo, in Spanish, and îwá-he'e, in Guarani (Martinez-Crovetto 1968).

The species flowers between October and November, and the fruits mature between January and May and are naturally dispersed by animals (Kinupp and De Barros 2007). From the perspective of use with livestock in the Pampa, native groves 
with A. spinescens offer feed for cattle (Guarino et al. 2018) from fruits fallen on the ground, and their dense canopies offer shade in the hottest periods of the year, highlighting potential in silvopasture systems. In addition to its use as forage, its fruit with sweet pulp has high potential as a food source and its seeds for extraction of vegetable oil (Kinupp and De Barros 2007; Teixeira et al. 2019). The popular use indicates that its seeds can also be consumed raw or roasted. In the region, mainly in Uruguay, they are commonly used for pies and are crunchy, like Brazil nuts and almonds.

Since its natural populations have low rates of value of importance $(0,98 \%)$ and the groves along rivers in the Pampa have been increasingly devastated, the species is now considered threatened in the biome (Ramos 2008). In the 1960s, studies found high concentration of fatty acids with high molecular weight, not common in essential oils of other local species (Powell and Smith Jr. 1966); however, it is still a neglected species in terms of scientific research. The vegetable oil of $A$. spinescens is registered as a major component oleic acid, which has high cicatrizant power (Dauber 2016). Popular knowledge also highlights that when consumed raw in a large quantity, still warm from the sun (picked from the tree), it can have laxative power.

\section{Anacauita}

\section{Schinus molle}

The Anarcadiaceae family has important representatives in Brazilian food culture, such as mango (Mangifera indica) and caju (Anacardium occidentale). One of the characteristics of this family is the presence of an anatomic structure that secretes terpenes and resins, which confer a special aroma to its representatives. In Brazil, there are 13 genera, 57 described species (17 endemic), highlighted by the genus Schinus, with 10 Brazilian species, and among them, 9 are found in the Pampa (Silva-Luz et al. 2020).

In this context, $S$. molle stands out, known as anacauita, piriquiteira, aroeirasalsa, or anacahuita in Spanish and aguará-ybá in Guarani and is quite a representative of the biome (Gomes et al. 2013). It is a perennial tree, 4 to $10 \mathrm{~m}$; it has a dense, rounded, and open canopy (Gomes et al. 2013). It flowers from August to November and bears fruit from December to March. It is important to honey production, and its fruits are highly appreciated by local avifauna.

Studies demonstrate that its leaves, stems, and fruits have medicinal properties. They are composed of volatile oils with a strong odor and various biological activities (Díaz et al. 2008; Giuffrida et al. 2020). The mature berries are used as an alternative to pepper in foods. The essential oil of the anacauita is registered to have important antibacterial, antifungal, and insecticidal activity, which supports the traditional use of the species for infections (Fenner et al. 2006; Santos et al. 2010; Tomazoni et al. 2017). Due to its tannin content, it is also used to cure leather. In addition to the potential of its resins and oils, its use as food is related to its aromatic potential, and it establishes its potential for extractivism or commercial planting, as is realized with S. terebinthifolius (Pich 2019) for the production of red pepper, an export product. 


\section{Garupá}

\section{Aloysia gratissima}

In Brazil, the Verbenaceae family includes 15 genera, 286 species with $63 \%$ of these endemic, and many with strong aromatic characteristics (Flora do Brasil 2020c). The Aloysia genera stands out and includes ten Brazilian species and three varieties (Moroni and O'Leary 2020), while Argentina is a possible center of dispersion (Silva et al. 2006). Among them, A. gratissima is found in Mexico to northeast Argentina, concentrated in the southern region of Brazil (Santos 2007). The botanic identification of the species is complex, and some authors affirm that there are two varieties: A. gratissima var. gratissima and A. gratissima var. sellowi (Moroni et al. 2016). A. gratissima is a bush that can reach 3 meters in height, with an irregular growth pattern. It flowers intensely through spring and summer (Ross et al. 2018). It is called garupá, alfazema-do-Brasil, mimo-do-Brasil, or cedrón-del-monte in Spanish and is well-known as a highly aromatic wild species.

It is locally used in popular medicine and is especially effective for bronchial, pulmonary, and bladder infections (Santos 2007). Moreover, the aqueous extracts of A. gratissima are efficient in the treatment of neurological, depressive, and inflammatory disorders, and its essential oils are effective in fighting bacteria that cause pneumonia and are used as insecticides against mosquito that carries dengue (Coelho and Coêlho 2006; Santos et al. 2016; Souza et al. 2020; Zeni et al. 2013).

Its direct use is highlighted by ornamental and landscaping applications for planting in groups and by its therapeutic potential due to its intense aromatic flowering. It is also ecologically important for honey production, and in traditional Gaucho cooking, garupá leaves are used to flavor meat dishes and are included in the popular infusion with erva-mate (Ilex paraguariensis), a species native to the Atlantic Forest originally used by the Indigenous Guarani who live in southern Brazil. In contemporary cooking, it is used as flavoring for other savory dishes and for juices and sweets.

\section{Capim-corona}

\section{Elionurus muticus}

Elionurus is a small genus with three species in Brazil that is part of the large Poaceae family (Flora do Brasil 2020d). Botanic classification of the genera is controversial, and the characteristic that separates the species has been the presence or not of a citric odor (Welker and Longhi-Wagner 2007). E. muticus, known as capimlimão or capim-corona in Brazil and pasto-limón or colia-peluda in Uruguay, is an herbaceous plant found in sandy soils (Hess et al. 2007; Marchi and Barbieri 2015). It flowers from October to December in erect, pilose, solitary stalks $8-10 \mathrm{~cm}$, which are silvery white in color with tones of pink and aromatic (Marchi and Barbieri 2015).

It is a native Gramineae that, since dominant in sandy soils of the Pampa, is not desired in cattle pasture. However, if well managed, in periods when it is more palatable to animals, it has potential use as forage. With rapid growth, its composition contains proteins, fibers, and minerals that can be combined with supplements to compose beef cattle and sheep diets (Bernardis 1998; O'Connor et al. 2011), especially the young plants, as a strategy for facing the Pampa winter. Another 
contemporary use of the species is related to the production of essential oils whose products can be found for sale by companies in this sector. The volatile oils of E. muticus has as their principal component citral, a compound of strong interest in the food, perfume, and cosmetics industries (Fuller 2013). Beyond these uses, local communities use capim-corona to treat various diseases. Their roots are chewed for tooth and stomach pain, and their aerial portions are sudoriparous and control fever (Chagonda and Fungirayi 2016). Studies have found E. muticus to have strong antibacterial and antifungal activity (Hess et al. 2007; Puppin et al. 2018).

\section{Final Considerations}

The consumption of native edible plants is an important strategy for supporting sustainable food systems. These foods have an important role in the promotion of a suitable and healthy diet, given that they can contribute to the conservation of environments and cultures while simultaneously expanding the range of nutrients accessed by the individuals who consume them. In the case of the Pampa, the expansion in the offer and consumption of edible, aromatic, and medicinal plants from the biome involves innovation processes that, although underway, are still a weak element in research and extension activities in the fields of agronomy and nutrition.

The supply of these plants now available for use as food, in large part from extractivism, and research underway, creates an opportunity to diversify diets and reflect on food choices of the local population. These plants, especially the fruits presented here, represent sources of fibers, minerals, vitamins, and antioxidant compounds whose deficiency is related to countless health problems that afflict the Brazilian population. The fruits are joined by medicinal and aromatic plants that have a proven quantity of bioactive compounds that promote good health. Thus, improving knowledge and the sustainable use of this nutritionally healthy food biodiversity, including its regular consumption in daily diets, is an action that exemplifies the win-win paradigm that is so necessary in times of crisis of human and planetary health. The Pampa territory comports innovative productive designs that can promote both environmental health and conservation of ecosystems and territorial development based on sustainability.

\section{References}

Andrade JMM, Aboy AL, Apel MA et al (2011) Phenolic composition in different genotypes of guabiju fruits (Myrcianthes pungens) and their potential as antioxidant and antichemotactic agents. J Food Sci 76. https://doi.org/10.1111/j.1750-3841.2011.02375.x

Athayde EA, Giehl ELH, Budke JC et al (2009) Fenologia de espécies arbóreas em uma floresta ribeirinha em Santa Maria, sul do Brasil. Rev Bras Biociências 7:43-51 
Barbosa MR, Sobral M, Proença C, et al (2015) Guettarda in Lista de Espécies da Flora do Brasil. In: Jard. Botânico do Rio Janeiro. http://floradobrasil.jbrj.gov.br/jabot/floradobrasil/FB171. Accessed 15 Sept 2014

Barzotto ILM (2019) Otimização de extratos de Eugenia involucrata DC. Universidade do Vale do paraíba

Bernardis AC (1998) Nutritive value of the grass Elionurus muticus (Spreng) Kuntze. Inf Tecnológica 9:227-230

BRASIL (2000) Programa Nacional de Conservação da Biodiversidade. A Convenção sobre Diversidade Biológica - CDB. In: Decreto Legis. no. 2. http://www.terrabrasilis.org.br/ ecotecadigital/pdf/serie-biodiversidade\%2D\%2D02-convencao-sobre-diversidade-biologica. pdf\%3E. Accessed 7 Oct 2020

Brasil (2005) RDC 269 de 22 de setembro de 2005: Regulamento Técnico sobre a ingestão diária recomendada (IDR) de proteína, vitaminas e minerais

BRASIL (2009) PORTARIA INTERMINISTERIAL No 239 de 21 DE JULHO de 2009

Büttow MV, Barbieri RL, Neitzke RS, Heiden G (2009) Conhecimento tradicional associado ao uso de butiás (Butia spp., arecaceae) no sul do Brasil. Rev Bras Frutic 31:1069-1075. https:// doi.org/10.1590/s0100-29452009000400021

Camlofski AM (2008) Caracterização do fruto de cerejeira (Eugenia involucrata DC) visando seu aproveitamento tecnológico. Universidade Estadual de Ponta Grossa

Carvalho PE (2008) Espécies arbóreas brasileiras. Embrapa Florestas, Colombo

Chagonda LS, Fungirayi B (2016) Antifungal activity of the essential oil of Elionurus muticus (Spreng) Kunth from Zimbabwe against Candida albicans, C. krusei and Cryptococcus neoformans. J Multidiscip Eng Sci Technol 3:5331-5335

Chomenko L, Bencke GA (2016) Nosso Pampa desconhecido. Fundação Z, Porto Alegre

Coelho AAM, Coêlho AAA (2006) Análise inseticida de extratos de plantas do bioma Cerrado sobre triatomíneos e larvas de Aedes aegypti. Universidade de Brasília

Curicaca, FLD, et al (2018) Conservação dos butiazais e salvaguarda da pecuária familiar em campo nativo na região de Quaraí, Rio grande do Sul

Dalla Nora C, Jablonski A, Rios AO et al (2014a) The characterisation and profile of the bioactive compounds in red guava (Psidium cattleyanum Sabine) and guabiju (Myrcianthes pungens (O. Berg) D. Legrand). Int J Food Sci Technol 49:1842-1849. https://doi.org/10.1111/ ijfs. 12493

Dalla Nora CD, Müller CDR, de Bona GS et al (2014b) Effect of processing on the stability of bioactive compounds from red guava (Psidium cattleyanum Sabine) and guabiju (Myrcianthes pungens). J Food Compos Anal 34:18-25. https://doi.org/10.1016/j.jfca.2014.01.006

Dauber B (2016) Elucidação dos componentes e avaliação da atividade antiquimiotáxica do óleo sa semente de Acanthosyris spinencens. Universidade Federal do Rio Grande do Sul

Dettke GA, Caires CS (2015) Santalaceae in Lista de Espécies da Flora do Brasil. In: Jard. Botânico do Rio Janeiro

Díaz C, Quesada S, Brenes O et al (2008) Chemical composition of Schinus molle essential oil and its cytotoxic activity on tumour cell lines. Nat Prod Res 22:1521-1534. https://doi. org/10.1080/14786410701848154

Santos SR dos, Marchiori JNC (2014) Anatomia da madeira de Myrcianthes pungens (O. Berg) D. Legrand (Myrtaceae). Balduinia 0:25-30. https://doi.org/10.5902/2358198014089

Duarte A, Hirota B, Campos R (2014) Avaliação da atividade antioxidante e antimicrobiana do extrato etanólico bruto e frações orgânicas obtidas a partir da casca do caule da espécie Guettarda uruguensis Cham \& Scthdl. (Rubiaceae). Rev Ciênc Farm Básica Apl 35:607-614

Duarte AFS, Krause MS, Martins ALC, Miguel OG (2017) Atividade fitotóxixa de Guettarda uruguensis (Rubiaceae) sobre a germinação e crescimento de sementes de Lactuca sativa. Visão acadêmica 18:5-13

Embrapa (2017) Rota dos Butiazais. 6

Faria JP, Almeida F, Silva LCR et al (2008) Caracterização da polpa do coquinho-azedo (Butia capitata var capitata). Rev Bras Frutic 30:827-829. https://doi.org/10.1590/ s0100-29452008000300045 
Fenner R, Betti AH, Mentz LA, Rates SMK (2006) Plantas utilizadas na medicina popular brasileira com potencial atividade antifúngica. Rev Bras Ciencias Farm J Pharm Sci 42:369-394. https:// doi.org/10.1590/S1516-93322006000300007

Ferrão TS, Ferreira DF, Flores DW et al (2013) Evaliation of composition and quality parameters of jelly palm (butia odorata) fruits from different regions of Southern Brazil. Food Research International 54:57-62. https://doi.org/10.1016/j.foodres.2013.06.002

Fior CS, Rodrigues LR, Calil AC et al (2010) Qualidade fisiológica de sementes de guabijuzeiro (Myrcianthes pungens (Berg) Legrand - Myrtaceae) em armazenamento. Rev Arvore 34:435-442. https://doi.org/10.1590/s0100-67622010000300007

Flora do Brasil (2020a) Myrtacea. In: em construção. http://floradobrasil.jbrj.gov.br/reflora/floradobrasil/FB171. Accessed 2 Jul 2020

Flora do Brasil (2020b) Eugenia. In: em construção. http://floradobrasil.jbrj.gov.br/reflora/floradobrasil/FB10338. Accessed 2 Jul 2020

Flora do Brasil (2020c) Verbenaceae. In: em construção. http://floradobrasil.jbrj.gov.br/reflora/ floradobrasil/FB246. Accessed 20 Oct 2020

Flora do Brasil (2020d) Poaceae. In: em construção. http://floradobrasil.jbrj.gov.br/reflora/floradobrasil/FB19. Accessed 2 Jul 2020

Fonseca LX (2012) Caracterização de frutos de butiazeiro (Butia odorata Barb. Rodr.) Noblick \& Lorenzi e estabilidade de seus compostos bioativos na elaboração e armazenamento de geleias. Universidade Federal de Pelotas

Fonseca MM (2014) Biologia reprodutiva de Butia odorata (Barb. Rodr.) Noblick. Universidade Federal de Pelotas

Fuller TN (2013) Caracterização genética e química e atividade biológica do óleo essencial de populações naturais de Elionurus muticus humb. \& bompl ex willd. Universidade Federal do Rio grande do Sul

Geymonat G, Rocha N (2009) M'botiá. Ecosistema unico en el mundo. Castillos: Casa Ambiental, 1st edn. Casa Ambiental, Montevideo

Giuffrida D, Martínez N, Arrieta-Garay Y et al (2020) Valorisation of Schinus molle fruit as a source of volatile compounds in foods as flavours and fragrances. Food Res Int 133:109103. https://doi.org/10.1016/j.foodres.2020.109103

Gomes GC, Cardoso JH, Ferrer RS et al (2013) Árvores da Serra dos Tapes: Guia de Identificação com Informações Ecológicas, Econômicas e Culturais. Embrapa Clima Temperado, Pelotas

Guarino E, Overbeck GE, Boldrini II et al (2018) Espécies de Plantas Prioritárias para Projetos de Restauração Ecológica em Diferentes Formações Vegetais no Bioma Pampa: Primeira Aproximação. Doc/Embrapa Clima Temperado 457:79

Guollo K (2019) Biologia floral e reprodutiva de guabijuzeiro, sete-capoteiro e ubajaizeiro. Universidade Tecnológica Federal do paraná

Hess SC, Peres MTLP, Batista AL et al (2007) Evaluation os seasonal changes in chemical composition and antibacterial activity of Elionurus muticus (Sprengel) O. Kuntze (Gramineae). Quim Nov 30:370-373

Hoffmann JF, Barbieri RL, Rombaldi CV, Chaves FC (2014) Butia spp. (Arecaceae): An overview. Scientia Horticulturae 179:122-131. https://doi.org/10.1016/j.scienta.2014.08.011

Institute of Medicine (2006) Dietary DRI reference intakes. National Academy of Sciences, Washington, D.C.

Institute of Medicine (2019) Dietary reference intakes for sodium and potassium. The National Academies Press, Washington, D.C.

Kinupp VF, De Barros IBI (2007) Observações Biológicas, Estudo Bromatológico e Potencial Econômico de Sombra-de-Touro. Rev Bras Biociências 5:66-68

Leitman P, Soares K, Henderson A, et al (2015) Arecaceae in Lista de Espécies da Flora do Brasil. In: Jard. Botânico do Rio Janeiro. http://floradobrasil.jbrj.gov.br/jabot/floradobrasil/FB34028. Accessed 15 Mar 2013

Lemos RPM, D'Oliveira CB, Rodrigues CR et al (2014) Modeling distribution of Schinus molle L. in the Brazilian Pampa: insights on vegetation dynamics and conservation of the biome. Ann For Res 57:1. https://doi.org/10.15287/afr.2014.272 
Lorenzi H (2008) Árvores brasileiras: Manual de identificação e cultivo de plantas arbóreas nativas do Brasil, 5th edn. Editora Plantarum, Nova Odessa - SP

Marchi MM, Barbieri RL (2015) Cores e Forma no Bioma Pampa: Gramíneas e ornamentais nativas, 1 st edn. Embrapa, Brasilia

Marchiori JNC, Alves FS (2011) Palmar de Coatepe (Quaraí, RS): enfoque fitogeográfico. Balduina 25:21-26

Marchiori INC, Elesbão LEG, Alvarez Filho A (1995) O palmar de Coatepe. Ciência Ambient 1:93-104

Marin R, Apel MA, Limberger RP et al (2008) Volatile components and antioxidant activity from some myrtaceous fruits cultivated in southern Brazil. Lat Am J Pharm:27

Martinez-Crovetto R (1968) Etnobiologica. Etnobiologica 4:1-24

Martins JS, Melo EM, Fallavena LP, Hertz PF (2019) Avaliação nutricional de Butiá (Butia yatai) processado. Segurança Aliment e Nutr 26:1-7

Matos TM, Muller NTG, M. D, et al (2019) Characterization of foliar secondary metabolites in Butia yatay (Mart.) Becc. Rev Tecnológica 28:31-38. https://doi.org/10.4025/revtecnol. v28i1.50962

Meerow AW, Noblick L, Borrone JW et al (2009) Phylogenetic analysis of seven WRKY genes across the palm subtribe attaleinae (Areceaceae) identifies Syagrus as sister group of the coconut. PLoS One 4:10-13. https://doi.org/10.1371/journal.pone.0007353

Mistura CC, Barbieri RL, Castro CM et al (2012) Caracterização de uma população natural de Butia odorata (Barb.Rodr.) Noblick\&lorenzi:cor e tamanho dos frutos. In: Encontro sobre pequenas frutas e frutas nativas do Mercosul. Embrapa Clima Temperado, Pelotas, p 80

Moroni P, O’Leary N (2020) Aloysia in Flora do Brasil 2020 em construção. In: Jard. Botânico do Rio Janeiro. http://floradobrasil.jbrj.gov.br/reflora/floradobrasil/FB15122. Accessed 2 Jul 2020

Moroni P, O'Leary N, Filloy J (2016) Species delimitation in the Aloysia gratissima complex (Verbenaceae) following the phylogenetic species concept. Bot J Linn Soc 180:193-212. https://doi.org/10.1111/boj.12369

Newton J (1986) Estudo anatômico da madeira de veludinho, Guettarda uruguensis Cham. et Schlecht. Ciência e Nat 1:115-123

Nicácio AE, Rotta EM, Boeing JS et al (2017) Antioxidant activity and determination of phenolic compounds from Eugenia involucrata DC. Fruits by UHPLC-MS/MS. Food Anal Methods 10:2718-2728. https://doi.org/10.1007/s12161-017-0840-3

Noblick LR (2011) Validation of the name Butia odorata. Palms 55:48-49

O'Connor TG, Martindale G, Morris CD et al (2011) Influence of grazing management on plant diversity of Highland Sourveld grassland, Kwazulu-Natal, South Africa. Rangel Ecol Manag 64:196-207. https://doi.org/10.2111/REM-D-10-00062.1

Oliveira AG (2018) Sistemática de Eugenia (Myrtaceae, Myrteae): evolução da flor e da inflorescência e implicações taxonômicas. Universidade de São Paulo

Pase do Prado A (2009) Aspectos autocológicos e silviculturais de Eugenia involucrata DC. Universidade Federal de Santa Maria

Patterer NI, Zucol AF, Fernández Pepi MG, Brea M (2019) Plant and soil phytolith analysis of a relictual community of Butia yatay in temperate-humid savannas (Entre Ríos, Argentina). Quat Int 525:126-139. https://doi.org/10.1016/j.quaint.2019.07.019

Pereira ZV (2007) Rubiaceae Juss. do Parque Estadual das Várzeas do Rio Ivinhema, Mato Grosso do Sul: florística, sistema reprodutivo, distribuição espacial e relações alométricas de espécies distílicas. Universidade Estadual de Campinas

Pereira ZV, Kinoshita LS (2013) Rubiaceae Juss. do Parque Estadual das Várzeas do Rio Ivinhema, MS, Brasil. Hoehnea 40:205-251

Piaggio M, Delfino L (2009) Florística y fitosociología de un bosque fluvial en Minas de Corrales, Rivera, Uruguay. Iheringia - Ser Bot 64:45-51

Pich RC (2019) Obtenção e caracterização do produto seco da pimenta rosa (Schinus terebinthifolius R.) por cast tape drying. Universidade Federal de Uberlândia 
Powell RG, Smith CR Jr (1966) New acetylenic fat acids from Acanthosyris spinescens seed oil. Biochemistry 5:625-631

Praderi R (1959) Notas preliminares acerca de la vegetación del río Uruguay medio. Boletín la Soc Taguató 1:33-45

Puppin DGPB, Barbosa JP, Oliveira TR et al (2018) Anti-Candida activity of the essential oil from Elionurus muticus: a preliminary study. Aust Dent Sci 3:2-4

Quadros FLF, Trindade JPP, Borba M (2008) A abordagem funcional da ecologia campestre como instrumento de pesquisa e apropriação do conhecimento pelos produtores rurais. In: Campos Sulinos. Ministério do Meio Ambiente, Brasilia, pp 206-213

Ramos G (2008) Florística y Fitosociología Leñosa de Rincón de Franquía, Bella Unión, Uruguay. Tesina, Universidad de la República del Uruguay

Ramos MO (2019) Cadeias agroalimentares sob o enfoque da soberania e segurança alimentar e nutricional: uma construção a partir do estudo de cadeias de frutas nativas da Mata Atlântica

Ramos MO, Cruz FT, Souza GC, Kubo RR (2017) Cadeias de Produtos da Sociobiodiversidade no Sul do Brasil: Valorização de Frutas Nativas da Mata Atlântica no Contexto do Trabalho com Agroecologia. Amaz - Rev Antropol 9:98. https://doi.org/10.18542/amazonica.v9i1.5485

Rivas M, Barbieri RL (2017) Butiá, Butia odorata. Instituto Interamericano de Cooperación para la Agricultura (IICA)

Rockett FC, Schmidt H, Pagno CH et al (2020) Native fruits from southern Brazil: Physicochemical characterization, centesimal composition, and mineral content. J Food Process Preserv 44:1-11. https://doi.org/10.1111/jfpp.14582

Rodrigues PRF, Barbieri RL, Costa JC, Morselli TBG (2008) Ocorrência de Butia lallemantii no município de Alegrete (RS) e ameaças às populações naturais. In: Encontro de Pós-graduação da UFPEL. Pelotas, RS, pp 0-3

Ross P, Muñoz J, Cracco P (2018) Flora Indígena del Uruguay: árboles y arbustos ornamentales. Agropecuaria Hemisferio Sur, Montevideo

Sampaio L, Almeida C (2009) Vitaminas antioxidantes na prevenção do câncer do colo uterino. Rev Bras Cancerol 55:289-296

Santos FM (2007) Aspectos ecofisiológicos de Aloysia gratissma (Gillies et Hook) Troncoso [Verbenaceae] associados à composição do óleo essencial e sua ação microbiana. Universidade Federal de Lavras

Santos ACA, Rossato M, Serafini LA et al (2010) Efeito fungicida dos óleos essenciais de Schinus molle L. e Schinus terebinthifolius Raddi, Anacardiaceae, do Rio Grande do Sul. Rev Bras Farmacogn 20:154-159

Santos FM, Pinto JEBP, Bertolucci SKV et al (2016) Chemical composition and antimicrobial activity of the essential oil from the leaves and flowers of Aloysia gratissima. Acta Hortic 1125:215-221. https://doi.org/10.17660/ActaHortic.2016.1125.27

Schlindwein G (2012) Implicações ecológicas da dormência de sementes em Butia odorata (Arecaceae). Universidade Federal do Rio Grande do Sul

Schmidt H (2018a) Caracterização físico-química, nutricional e de compostos ativos de sete espécies da família Myrtaceae nativas da região sul do Brasil. Universidade Federal do Rio Grande do Sul

Schmidt S (2018b) Caracterização físico-química, nutricional e de compostos bioativos de sete espécies da família Myrtaceae nativas da região sul do Brasil. Universidade Federal do Rio Grande do Sul

Seraglio SKT, Schulz M, Nehring P et al (2018) Nutritional and bioactive potential of Myrtaceae fruits during ripening. Food Chem 239:649-656. https://doi.org/10.1016/j. foodchem.2017.06.118

Sganzerla M (2010) Caracterização físico-química e capacidade antioxidante do butiá. universidade Federal de Pelotas

$\mathrm{SiBBr}$ (2020) Sistema de informação sobre a Biodiversidade Brasileira. https://ala-bie.sibbr.gov. br/ala-bie/species/364658\#classification. Accessed 1 Jul 2020 
Silva CC, Vandresen F, de Oliveira CMA et al (2006) Chemical composition of Aloysia gratissima (Gill. et Hook) Tronc. (Verbenaceae). Biochem Syst Ecol 34:593-595. https://doi. org/10.1016/j.bse.2006.01.001

Silva-Luz CL, Mitchell JD, Pirani JR, Pell SK (2020) Anacardiaceae in Flora do Brasil 2020 em construção. In: Jard. Botânico do Rio Janeiro. http://floradobrasil.jbrj.gov.br/reflora/floradobrasil/FB1199. Accessed 20 Oct 2020

Silveira S, De Lucena EV, Pereira TF et al (2011) Atividade anticolinesterásica dos frutos de Myrcianthes pungens (O. Berg) D.Legrand (Myrtaceae). Arq Ciência da Saúde da Unipar 15:127-133. https://doi.org/10.25110/arqsaude.v15i2.2011.3707

Soares KP, Longhi SJ, Neto LW, De Assis LC (2014) Palmeiras (Arecaceae) no Rio Grande do Sul, Brasil. Rodriguesia 65:113-139

Sobral M, Proença C, Souza M, et al (2015) Lista de Espécies da Flora do Brasil. In: Myrtaceae List. Espécies da Flora do Bras

Sosinski ÊE, Urruth LM, Barbieri RL et al (2019) On the ecological recognition of Butia palm groves as integral ecosystems: why do we need to widen the legal protection and the in situ/ on-farm conservation approaches? Land Use Policy 81:124-130. https://doi.org/10.1016/j. landusepol.2018.10.041

Souza RC, Baldisserotto B, Melo JFB et al (2020) Dietary Aloysia triphylla essential oil on growth performance and biochemical and haematological variables in Nile tilapia. Aquaculture 519:734913. https://doi.org/10.1016/j.aquaculture.2019.734913

Strack MH, Souza CG (2012) Antocianinas, catequinas e quercetina: evidências na prevenção e no tratamento das doenças cardiovasculares. Rev Bras Nutr Clin 27:43-50

Suertegaray DMA, Silva LAP (2009) Tchê Pampa: histórias da natureza gaúcha. In: Patta Pillar V et al (eds) Campos Sulinos: conservação e uso sustentável da biodiversidade, 1st edn. Ministério do Meio Ambiente, Brasília, p 403

Takáts A, Toselli C (2015) Estudio ambiental y turístico de la Reserva Natural Las Piedras, Gualeguaychú, Entre Ríos, Argentina. Tiempo de gestión 21:40

Teixeira N, Melo JCS, Batista LF et al (2019) Edible fruits from Brazilian biodiversity: a review on their sensorial characteristics versus bioactivity as tool to select research. Food Res Int 119:325-348. https://doi.org/10.1016/j.foodres.2019.01.058

Tomazoni EZ, Ribeiro RTS, Schwambach J (2017) Potencial fungitóxico dos óleos essenciais de Schinus molle L. e Schinus terebinthifolius Raddi contra fungos patogênicos do tomateiro. Rev Bras Agroecol 12:7

Tutwiler A, Padulosi S, Hunter D (2017) Securing sustainable and nutritious food systems through mainstreaming agricultural biodiversity: an interdisciplinary study. Lancet 389:S22. https:// doi.org/10.1016/s0140-6736(17)31134-0

Vasconcelos TNC, Proença CEB, Ahmad B et al (2017) Myrteae phylogeny, calibration, biogeography and diversification patterns: increased understanding in the most species rich tribe of Myrtaceae. Mol Phylogenet Evol 109:113-137. https://doi.org/10.1016/j.ympev.2017.01.002

Venzke TS (2012) Florística de comunidades arbóreas no Município de Pelotas, Rio Grande do Sul. Rodriguésia 63:571-578

Vinholes J, Lemos G, Lia Barbieri R et al (2017) In vitro assessment of the antihyperglycemic and antioxidant properties of araçá, butiá and pitanga. Food Biosci 19:92-100. https://doi. org/10.1016/j.fbio.2017.06.005

Welker CAD, Longhi-Wagner HM (2007) A família Poaceae no Morro Santana, Rio Grande do Sul, Brasil. Rev Bras Biociêncas 5:53-92

Zeni ALB, Zomkowski ADE, Maraschin M et al (2013) Evidence of the involvement of the monoaminergic systems in the antidepressant-like effect of Aloysia gratissima. J Ethnopharmacol 148:914-920. https://doi.org/10.1016/j.jep.2013.05.042 